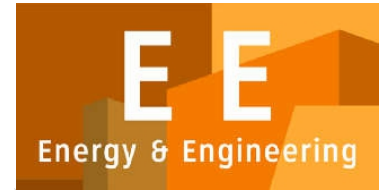

PAPER - OPEN ACCESS

\title{
Implementasi Pengembangan Pariwisata Halal di Lombok
}

\author{
Author $\quad:$ Aulia Nastiti Utami, dkk \\ DOI $\quad: 10.32734 /$ ee.v2i1.418 \\ Electronic ISSN $\quad: 2654-704 \mathrm{X}$ \\ Print ISSN : $2654-7031$
}

Volume 2 Issue 1 - 2019 TALENTA Conference Series: Energy \& Engineering (EE)

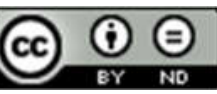

This work is licensed under a Creative Commons Attribution-NoDerivatives 4.0 International License.

Published under licence by TALENTA Publisher, Universitas Sumatera Utara

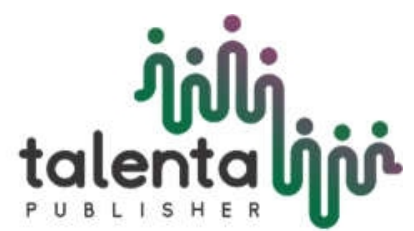




\section{jibli (and TALENTA Conference Series}

Available online at https://talentaconfseries.usu.ac.id

\title{
Implementasi Pengembangan Pariwisata Halal di Lombok
}

\author{
Aulia Nastiti Utami ${ }^{\mathrm{a}}$, M. Sani Roychansyah ${ }^{\mathrm{b}}$, Medy Krisnany S. ${ }^{\mathrm{c}}$ \\ a,b,c Departemen Teknik Arsitektur dan Perencanaan, Fakultas Teknik, Universitas Gadjah Mada \\ Departemen Teknik Arsitektur dan Perencanaan, Jalan Grafika 2, Sinduadi, Mlati, Senolowo, Sinduadi, Mlati, Kabupaten Sleman, Daerah \\ Istimewa Yogyakarta \\ aulia.utami19@gmail.com
}

\begin{abstract}
Abstrak
Pariwisata adalah sektor yang berkembang. Salah satu indikatornya adalah dari meningkatnya perjalanan global. Konsep pariwisata halal secara global, salah satunya adalah karena peningkatan populasi Muslim dan tingginya jumlah perjalanan wisata yang dilakukan. Karenanya konsep pariwisata halal terus bermunculan dan terus dibahas secara global. Berdasarkan hal ini, penelitian ini penting dan perlu dilakukan dengan tujuan merumuskan pelaksanaan pengembangan pariwisata halal di Lombok. Tujuan umum ini akan dijabarkan dalam tujuan khusus, yaitu: (a) Melakukan studi tentang tujuan wisata halal di Lombok (b) Melakukan studi komponen pengembangan pariwisata halal di Lombok. Penelitian ini menggunakan pola pikir deduktif (metode penalaran), dengan pendekatan rasionalistik dan metode penelitian kualitatif. Wilayah dalam penelitian ini adalah Pulau Lombok yang merupakan bagian dari administrasi Provinsi Nusa Tenggara Barat. Sampel dalam penelitian ini terdiri dari dua jenis sampel yaitu sampel tujuan wisata dan responden. Pengukuran yang dilakukan dalam penelitian ini adalah dalam bentuk metode skoring atau pembobotan. Penilaian didasarkan pada skala Likert. Berdasarkan hasil analisis menunjukkan bahwa tipologi yang membentuk implementasi pengembangan pariwisata halal di Lombok adalah bahan baku, destinasi dan objek wisata, fasilitas di objek wisata, dan institusi.
\end{abstract}

Kata kunci: pariwisata, wisata halal, Lombok

\begin{abstract}
Tourism is a growing sector. One of the indicators is from increasing global travel. The concept of halal tourism globally, one of which is due to an increase in the Muslim population and the high number of tourist trips made. Therefore the concept of halal tourism continues to emerge and continue to be discussed globally. Based on this, this research is important and needs to be done with the aim of formulating the implementation of halal tourism development in Lombok. This general objective will be elaborated in specific objectives, namely: (a) Conduct study of halal tourism destinations in Lombok (b) Conduct a study of the components of halal tourism development in Lombok. This study uses a deductive mind set (method of reasoning), with a rationalistic approach and qualitative research methods. The area in this study is the island of Lombok which is part of the administration of the Province of West Nusa Tenggara. The sample in this study consisted of two types of samples namely sample tourist destinations and respondents. Measurements made in this study are in the form of scoring or weighting methods. Scoring is based on a Likert scale. Based on the results of the analysis shows that the typology that forms the implementation of halal tourism development in Lombok is raw materials, destinations and attractions, facilities in tourist attractions, and institutions.
\end{abstract}

Keywords: tourism, halal tourism, Lombok

\section{Pendahuluan}

Pariwisata merupakan sektor yang terus berkembang. Salah satu indikatornya adalah dari meningkatnya perjalanan wisata secara global. Disamping itu, hal lain yang mengalami peningkatan secara global adalah populasi muslim dunia. Hasil penelitian menunjukkan bahwa dalam 20 tahun ke depan populasi muslim dunia akan meningkat menjadi seperempat dari jumlah manusia di dunia. Peningkatan ini berimbas pada peningkatan perjalanan wisata yang 
dilakukan umat muslim secara global. Peningkatan perjalanan wisata dan peningatan populasi muslim secara global memungkinkan terjadinya peningkatan perjalanan wisata yang dilakukan wisatawan muslim.

Berdasarkan kondisi tersebut, maka memunculkan konsep wisata halal atau wisata yang ramah bagi perjalanan wisata keluarga mupun wisatawan muslim. Konsep ini mulai berkembang sejak maraknya publikasi mengenai prospek perkembangan pariwsata halal yang dilakukan oleh beberapa lembaga survei pada beberapa tahun terakhir. Pengembangan pariwisata halal pun menyebar hingga ke Indonesia. Sebagai salah satu negara dengan populasi penduduk muslim terbanyak di dunia, kini Indonesia mulai turut mengembangkan pariwisata halal. Lombok, dalam hal ini yang sebagai perwakilan dari Provinsi Nusa Tenggara Barat menjadi salah satu daerah pengembangan pariwisata halal di Indonesia, bahkan dinilai telah unggul dalam dalam melakukan upaya pengembangan pariwisata halal. Hal ini dibuktikan dengan adanya perolehan dua penghargaan sebagai World Best Halal Tourism Destination dari World Halal Travel Summit yang merupakan ajang penghargaan bidang pariwisata halal di tingkat internasional. Meskipun demikian belum ditemukan adanya ulasan atau bentuk implementasi pengembangan wisata halal di Lombok. Oleh sebab itu perlu adanya kajian dan perumusan dari implementasi pengembangan pariwisata halal di Lombok

\section{Tinjauan Pustaka}

\subsection{Definisi Pariwisata Halal}

Terkait dengan definisi, banyak ahli atau peneliti mendefinisikan pengertian mengenai pariwisata halal, dan keyword dari pariwisata halal antara lain: ajaran/hukum syariah, memenuhi kebutuhan wisatawan muslim, tidak hanya makanan tapi keselurahan sistem dari pariwisata, serta dapat berupa jenis wisata religi dan jenis wisata lainnya. Maka kesimpulan yang dapat diambil mengenai definisi pariwisata halal adalah merupakan salah satu jenis wisata yang bertumpu pada ketentuan syariah dalam penyediaan produk dan layanan pariwisata untuk memenuhi kebutuhan wisatawan muslim, khususnya, dan non muslim, secara umum.

\subsection{Kriteria Pariwisata Halal}

Kriteria pariwisata halal juga menjadi dasar dalam penilaian dalam penelitian ini (tabel 1).

Tabel 1. Kriteria Pariwisata Halal

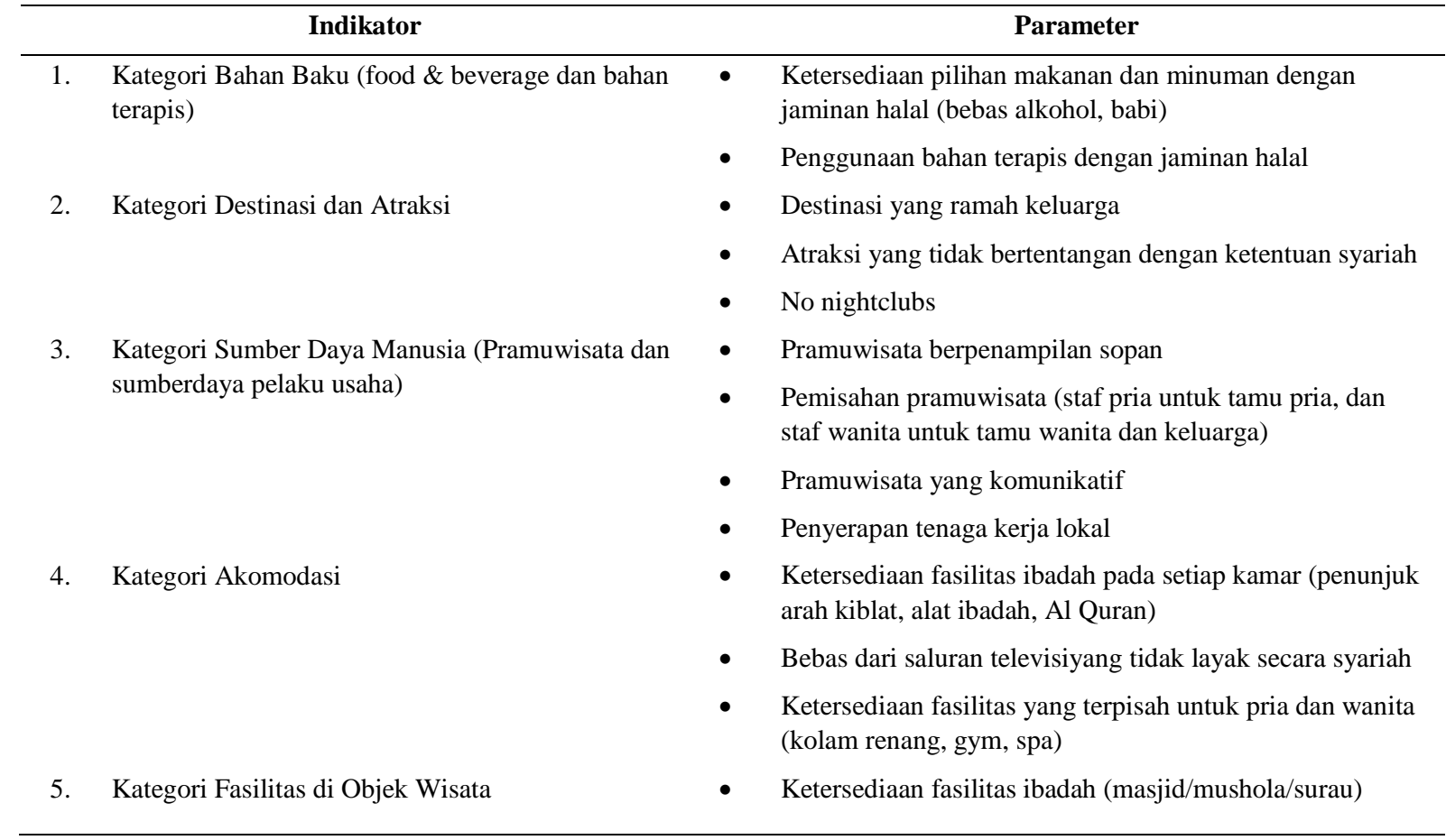


- $\quad$ Ketersediaan fasilitas bersuci yang layak (toilet dan tempat wudhu)

6. Kategori Keuangan

7. Kategori Pemasaran dan Sasaran Wisatawan

8. Kategori Keamanan dan Kenyamanan

9. Kategori Aksesibilitas
- Adanya pengingat waktu ibadah

- Keuangan berbasis syariah (tidak ada perniagaan barang yang dianggap haram, penggunaan prinsip berzakat)

- Kedatangan wisatawan muslim

- $\quad$ Promosi dan branding yang sesuai

- Terjaminnya keamanan dan suasana kondusif untuk berwisata dan berbisnis

- Terjaganya kebersihan sanitasi dan lingkungan

- Ketersediaan moda transportasi (terutama konektivitas udara)

- Ketersediaan fasilitas penunjang di bandara (mushola, toilet, tempat bersuci/wudhu)

- Ketersediaan transportasi dengan biaya sesuai standar

- Kemudahan akses informasi tentang wisata halal

10. Kategori Kelembagaan
- Terdapat kelembagaan yang mendukung sertifikasi halal

\section{Metodologi Penelitian}

Penelitian ini menggunakan pola pikir (metode penalaran) deduktif, dengan pendekatan rasionalistik dan metode penelitian kualitatif. Wilayah dalam penelitian ini adalah pulau Lombok yang menjadi bagian dari administrasi Provinsi Nusa Tenggara Barat.

\subsection{Sampel Penelitian}

Sampel dalam penelitian ini terdiri atas dua jenis sampel yaitu sampel destinasi wisata dan responden. Dalam penelitian ini, populasi yang akan menjadi subyek penelitian tidak diketahui secara pasti. Namun tidak memungkin jika mengambil keseluruhan populasi yang ada di wilayah penelitian. Oleh sebab itu untuk penentuan sampel yang merupakan wisatawan menggunakan dasar teori Roscoe yang dikutip Sekaran [3]. Berdasarkan teori Roscoe maka ukuran sampel adalah sejumlah 30 sampel. Teknik sampling yang digunakan adalah Simple Random Sampling (Sampel Acak Sederhana). Penelitian kualitatif memiliki kaitan erat dengan faktor-faktor kontekstual. Sampling dalam kualitatif ialah untuk menjaring sebanyak mungkin informasi dari berbagai macam sumber dan bangunannya (constructuctions). Dengan demikian tujuannya bukanlah memusatkan diri pada adanya perbedaan-perbedaan yang nantinya dikembangkan ke dalam generalisasi. Oleh sebab itu pada penelitian kualitatif tidak ada sampel acak, tetapi sampel bertujuan (purposive sample) [2].

\subsection{Metode Pengukuran}

Pengukuran dilakukan sebagai tindak lanjut dari pengumpulan data. Dimana metode ini akan digunakan dalam melakukan analisis data. Pengukuran yang dilakukan dalam penelitian ini adalah berupa metode skoring atau pembobotan. Skoring dilakukan berdasarkan skala likert. Skala Likert merupakan metode pengukuran yang digunakan untuk mengukur sikap, pendapat dan persepsi seseorang atau kelompok orang tentang fenomena sosial [3]. Dalam penelitian ini skoring dilakukan pada dua pembahasan yaitu skoring pada karakteristik destinasi wisata halal, dan skoring pada tipologi komponen pariwisata halal. Inti dari metode skoring yang digunakan adalah sama, perbedaannya hanya pada parameter jumlah skor yang berdasarkan oleh jumlah pertanyaan (pada skoring karakteristik destinasi wisata halal) dan berdasarkan jumlah responden (pada skoring tipologi komponen pariwisata halal). Pada penelitian ini, penyusun menetapkan kriteria pemberian skor menjadi 3 yaitu (tabel 2): 
Tabel 2. Bobot Kriteria Penilaian

\begin{tabular}{lll}
\hline Gradasi Nilai & Skor & Keterangan / parameter \\
\hline Buruk & 1 & Tidak tersedia \\
Cukup & 2 & Tersedia, kondisi kurang hingga cukup baik \\
Baik & 3 & Tersedia, kondisi baik hingga sangat baik \\
\hline
\end{tabular}

Pembagian skor pada masing-masing kelas/kategori untuk penilaian destinasi wisata adalah sebagai berikut (tabel 3):

Tabel 3. Kategori Penilaian Destinasi Wisata

\begin{tabular}{ccc}
\hline Kategori & Jumlah Skor & Rata-Rata \\
\hline Buruk & $24-40$ & $1,0-1,67$ \\
Cukup & $41-57$ & $1,68-2,35$ \\
Baik & $58-74$ & $2,36-3,03$ \\
\hline
\end{tabular}

Pembagian skor pada masing-masing kelas/kategori untuk penilaian persepsi wisatawan adalah sebagai berikut (tabel 4):

Tabel 4. Kategori Penilaian Persepsi Wisata

\begin{tabular}{ccc}
\hline Kategori & Jumlah Skor & Rata-Rata \\
\hline Buruk & $30-50$ & $1,0-1,67$ \\
Cukup & $51-71$ & $1,68-2,35$ \\
Baik & $72-92$ & $2,36-3,03$ \\
\hline
\end{tabular}

\subsection{Metode Analisis}

Metode analisis yang digunakan dalam penelitian ini adalah analisis deskriptif. Analisis ini digunakan untuk menjelaskan skoring yang telah dilakukan melalui metode pengukuran. Juga untuk mendeskripsikan hasil dari pengumpulan data yang telah dilakukan.

\section{Hasil dan Pembahasan}

\subsection{Potensi Pengembangan Pariwisata Halal Di Lombok}

Pariwisata di Nusa Tenggara Barat, khususnya di Lombok mengalami perkembangan. Hal ini dapat dilihat dari berbagai faktor diantaranya seperti jumlah wisatawan dan juga keragaman aktivitas wisata. Jumlah wisatawan yang datang cenderung mengalami peningkatan setiap tahunnya, hingga sekitar 20 persen. Sedangkan keragaman aktivitas wisata salah satunya terlihat dari adanya pengenalan konsep pariwisata baru berupa wisata halal. Pengembangan wisata halal di Lombok merujuk pada provinsi Nusa Tenggara Barat secara keseluruhan (Pulau Lombok dan Sumbawa). Mengingat besarnya potensi pariwisata yang berkembang di Nusa Tenggara Barat menjadikannya salah satu tujuan destinasi wisata "beyond Bali". Nama Lombok yang tertera dalam pengembangan wisata halal didasari oleh beberapa hal diantaranya: 
- Sebutan pulau seribu masjid yang melekat pada nama Lombok

- Keragaman jenis destinasi/atraksi wisata untuk pariwisata halal ditinjau lebih cocok di Lombok. Sedangkan untuk Pulau Sumbawa (daerah Sumbawa-Dompu-Bima) memiliki segmen wisata adventure dan wisatawan backpacker.

- Kesiapan fasilitas pendukung wisata di Pulau Lombok lebih matang (hotel, restoran, maupun kelengkapan fasilitas di destinasi)

Oleh sebab itu, nama Lombok dipilih menjadi ikon atau dapat disebut branding bagi salah satu destinasi wisata dalam pengembangan pariwisata halal di Indonesia.

Dalam proses pematangan konsep pariwisata halal, diketahui bahwa terdapat wisatawan dari Timur Tengah yang turut mengisi daftar jumlah wisatawan mancanegara pada data statistik tahun 2016. Tahun 2016 tercatat adanya kunjungan wisatawan dari Timur Tengah dengan jumlah yang semakin meningkat setiap bulannya[1].

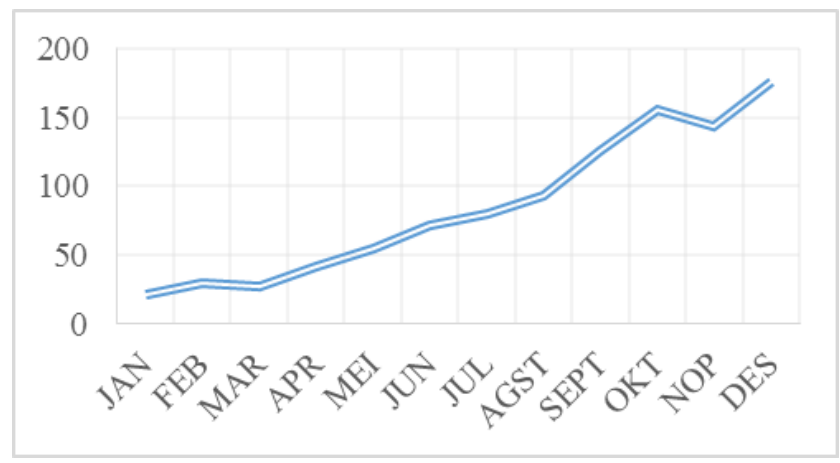

Gambar 1. Tren Kunjungan Wisatawan Mancanegara Asal Timur Tengah Tahun 2016

Sumber: Buku Statistik Kebudayaan dan Pariwisata Provinsi Nusa Tenggara Barat, 2016 [5]

Keberadaan peningkatan jumlah kunjungan wisatawan, karakteristik yang mendukung seperti sebutan sebagai pulau seribu masjid dan jenis destinasi maupun atraksi wisata, serta kelengakapan fasilitas pendukung wisata menjadikan Lombok memiliki potensi untuk pengembangan konsep pariwisata halal (gambar 1).

\subsection{Analisis Destinasi Wisata Halal Di Lombok}

Analisis destinasi wisata halal dilakukan pada sampel destinasi yang terdiri dari jenis wisata alam, budaya, dan buatan. Masing-masing destinasi akan dianalisis berdasarkan karakteristik dan hasil skoring penilaian. Penilaian dilakukan dengan cara memberi skor pada masing-masing indikator berdasarkan kriteria pariwisata halal. Kemudian dijumlahkan dan dikelompokkan dalam range jumlah skor yang telah ditetapkan. Berdasarkan hasil observasi lapangan, diketahui bahwa secara keseluruhan jumlah skor berada pada kategori baik. Dari 11 destinasi wisata yang menjadi sampel, hanya tiga destinasi yang berada pada kategori cukup yaitu destinasi dengan jenis wisata alam berupa pantai dan satu destinasi jenis wisata buatan (tabel5).

Tabel 5. Penilaian Sampel Destinasi Wisata

\begin{tabular}{clcl}
\hline Jenis Wisata & \multicolumn{1}{c}{ Destinasi } & Skor & Kategori \\
\hline ALAM & Pantai Ampenan & 58 & Baik \\
& Pantai Senggigi & 48 & Cukup \\
& Pantai Kuta & 46 & Cukup \\
& Air Terjun Benang Kelambu & 58 & Baik \\
\multirow{3}{*}{ BUDAYA } & Taman Narmada & 62 & Baik \\
& Masjid Kuno Bayan & 58 & Baik \\
& Desa Tradisional Sade & 62 & Baik \\
& Desa Tradisional Sembalun & 58 & Baik \\
& Islamic Center & 65 & Baik \\
& Bendungan Batujai & 48 & Cukup \\
& Aik Bukak & 58 & Baik \\
\hline
\end{tabular}


Berdasarkan hasil skoring, jenis wisata budaya memiliki karakteristik yang lebih sesuai untuk merepresentasikan konsep wisata halal (gambar 2). Hal ini didasari oleh kondisi sebagai berikut:

- Implementasi pengembangan wisata budaya di Lombok tidak bertentangan dengan ketentuan halal dalam indikator pengembangan wisata halal. Sesuai dengan literatur pada indikator pengembangan wisata halal yang mencakup ketentuan seperti no nightclubs, ketersediaan pilihan makanan dan minuman dengan jaminan halal (bebas alkohol, babi), family-friendly, destination muslim traveler and general safety, serta muslim visitor arrivals dapat terimplementasi dengan baik pada destinasi wisata budaya. Sehingga atraksi yang ditawarkan dapat dinikmati oleh semua kelompok wisatawan.

- Wisata budaya memiliki nilai keindahan tidak hanya dari segi fisik namun juga non fisik seperti nilai sejarah serta keunikannya dengan destinasi wisata lainnya.

- Wisata budaya menujukkan adanya kearifan lokal yang dapat menjadi nilai tambah sebagai dasar pertimbangan dalam mengunjungi destinasi wisata budaya.

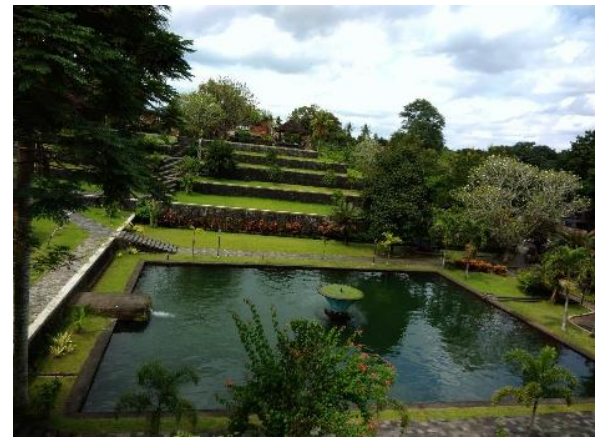

(a) Taman Narmada

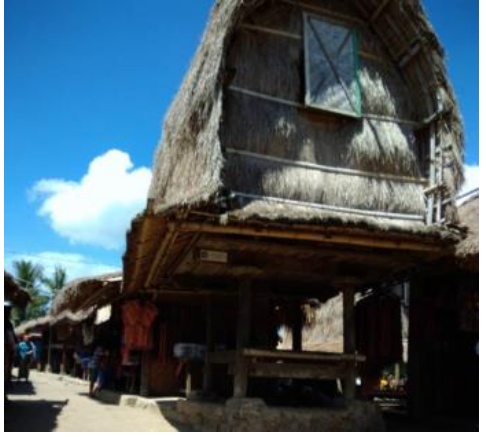

(b) Desa Tradisional Sade

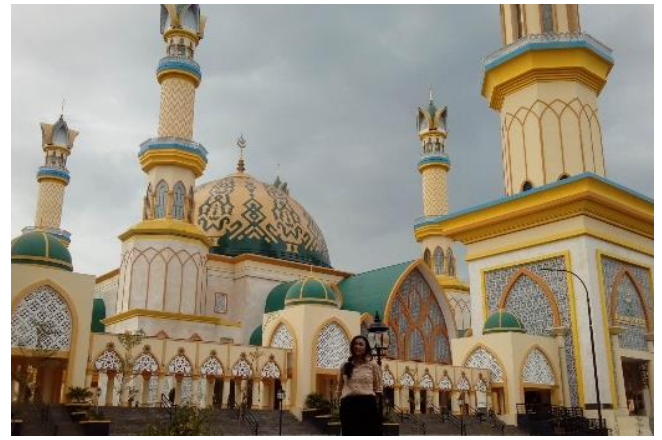

(c) Islamic Center

Gambar 2. Hasil Penilaian Sampel Destinasi Wisata Berdasar Jenis Wisata Sumber : Dokumen Pribadi

\subsection{Analisis Tipologi Komponen Pengembangan Pariwisata Halal Di Lombok}

Pengembangan implementasi pariwisata halal di Lombok dalam penelitian ini menggunakan kriteria yang telah ditentukan sebelumnya. Kriteria tersebut merupakan hasil komparasi dari berbagai sumber seperti penelitian, jurnal, artikel, maupun seminar yang terkait dengan tema pariwisata halal. Kriteria tersebut kemudian menjadi komponen bagi penilaian atas pengembangan pariwisata halal di Lombok. Terdapat 10 komponen yang menjadi dasar penilaian pengembangan wisata halal yaitu Kategori Bahan Baku (food \& beverage dan bahan terapis), Kategori Destinasi dan Atraksi, Kategori Sumber Daya Manusia (Pramuwisata dan sumberdaya pelaku usaha), Kategori Akomodasi, Kategori Fasilitas di Objek Wisata, Kategori Keuangan, Kategori Pemasaran dan Sasaran Wisatawan, Kategori Keamanan dan Kenyamanan, Kategori Aksesibilitas, dan Kategori Kelembagaan.

Untuk dapat melihat bentuk implementasinya, dilakukan penilaian salah satunya berdasarkan persepsi wisatawan, dimana dalam penilaian tersebut yang menggunakan persepsi wisatawan, terdapat 8 komponen yang menjadi poin penilaiannya. Eliminasi dilakukan pada kategori keuangan dan kelembagaan. Kategori keuangan dengan sistem syariah dinilai tidak dirasakan langsung oleh wisatawan, sedangkan dalam penilaian destinasi wisata (pada Analisis Destinasi Wisata Halal) kategori keuangan diikutsertakan karena menjadi hal yang diperhatikan oleh peneliti. Sedangkan untuk kelembagaan, eliminasi dilakukan karena aspek kelembagaan memiliki ruang lingkup secara makro yaitu Provinsi Nusa Tenggara Barat.

Berdasarkan hasil persepsi wisatawan, skor tertinggi adalah pada kategori aksesibilitas. Kemudian diikuti oleh kategori bahan baku, destinasi dan bahan baku, akomodasi, serta pemasaran dan sasaran wisatawan merupakan kategori yang juga memperoleh nilai rata-rata tinggi pada parameter di dalamnya.

- Bahan baku $\rightarrow$ makanan dan minuman halal

- Destinasi dan atraksi $\rightarrow$ layak dinikmati keluarga

- Akomodasi $\rightarrow$ fasilitas ibadah tiap kamar 
- Pemasaran dan sasaran wisatawan $\rightarrow$ kedatangan wisatawan muslim

- Aksesibilitas $\rightarrow$ Ketersediaan moda transportasi (terutama konektivitas udara)

Dapat disimpulkan bahwa berdasarkan persepsi wisatawan, secara keseluruhan implementasi komponen pengembangan wisata halal di Lombok dapat diklasifikasikan baik. Klasifikasi baik ini mengarah pada lima kategori dengan perolehan nilai rata-rata tertinggi. Kondisi ini menunjukkan bahwa implementasi yang dirasakan oleh wisatawan adalah mengarah pada kelima ketegori tersebut. selain itu jika dirata-rata pada delapan kategori yang dinilai oleh persepsi wisatawan menunjukkan hasil skor pada klasifikasi baik. Hal ini disebabkan karena secara eksisting masing-masing komponen tersebut telah terimplementasi pada pengembangan pariwisata di Lombok. Keberadaan pengembangan pariwisata halal adalah sebagai penguat atas keberadaan komponen-komponen tersebut.

\subsection{Implementasi Pengembangan Pariwisata Halal Di Lombok}

Berdasarkan kajian yang telah dilakukan, secara umum bentuk implementasi pengembangan pariwisata halal di Lombok adalah berupa kesiapan, terutama dari sisi kelembagaan. Hal ini terutama dinilai setelah adanya pernyataan penetapan Lombok sebagai Wisata Halal. Secara eksisting, beberapa kategori/komponen yang menjadi indikator dan parameter penilaian telah terimplementasi sebelumnya, kemudian didukung adanya penetapan Lombok sebagai wisata halal maka hal ini semakin menguatkan bentuk implementasi atas kategori/komponen tersebut. Kondisi ini membuktikan bahwa adanya penetapan ini adalah sebagai proses kunci dalam pengembangan pariwisata halal di Lombok. Bentuk implementasi internal, yang berasal dari dalam wilayah tersebut seperti bahan baku makanan dan minuman halal, lalu fasilitas ibadah di objek maupun bandara merupakan kondisi yang secara eksisting sudah ada, namun posisinya semakin dikuatkan dengan adanya pengembangan wisata halal. Hal ini disebabkan karena keberadaan masyarakat secara mikro (Lombok) maupun makro (Indonesia) adalah beragama Islam. Meskipun demikian, dalam pengembangan pariwisata yang berorientasi hingga pada skala internasional, keberadaan kualitas dan kuantitas yang baik perlu diperhatikan. Oleh sebab itu, perlu adanya upaya sertifikasi untuk menguatkan keyakinan atas halalnya produk tersebut. Upaya sertifikasi tersebut merupakan salah satu peran kelembagaan, dimana kelembagaan mendukung apa yang menjadi potensi yang sudah ada di dalam wilayah tersebut. Sehingga dapat dikatakan bahwa peran kelembagaan sebagai faktor eksternal menjadi salah satu pendukung atas keberadaan potensi eksisting (internal) diantaranya seperti bahan baku makanan dan minuman.

Dalam proses pengembangannya, 10 indikator yang digunakan secara umum dianggap sudah memiliki bentuk implementasi yang baik untuk mendukung pariwisata halal di Lombok. Masing-masing indikator memiliki ciri yang berbeda dan memiliki keterkaitan antar satu dengan lainnya. Seperti indikator bahan baku dan akomodasi yang memiliki keterkaitan dengan indikator kelembagaan, dimana oleh kelembagaan terdapat badan atau lembaga yang bertugas untuk mensertifikasi bahan baku dan juga akomodasi. Sedangkan untuk indikator pemasaran dan sasaran serta indikator aksesibilitas keterkaitan dengan kelembagaan adalah berupa upaya pemasaran yang dilakukan oleh pemerintah maupun pelaku usaha wisata untuk memperkenalkan pariwisata halal Lombok secara internasional dengan cara menggelar acara promosi wisata halal bahkan ke wilayah/negara dengan penduduk muslim sebagai minoritasnya. Keterkaitan antar indikator ini kemudian membentuk tipologi yang menjadi ciri bagi pengembangan wisata halal.

\section{Kesimpulan}

Rumusan implementasi pengembangan pariwisata halal adalah berupa terbentuknya tipologi pengembangan pariwisata halal di Lombok. Tipologi ini didasari oleh indikator yang digunakan sebagai penilaian atas pengembangan wisata halal di Lombok. Terdapat sepuluh indikator yang bersumber dari jurnal maupun kriteria yang digunakan lembaga internasional dalam pendeskripsian dan penilaian pariwisata halal. Berdasarkan hasil analisis tipologi yang menjadi pembentuk implementasi pengembangan wisata halal di Lombok adalah bahan baku, destinasi dan atraksi, fasilitas di objek wisata, dan kelembagaan. Hasil ini juga diperoleh dari matriks keterkaitan antar indikator, dimana indikator kelembagaan memiliki keterkaitan terbanyak dengan indikator lainnya. Hal ini disebabkan karena kelembagaan menjadi salah satu dasar dan awal dari adanya pengembangan wisata halal di Lombok. Dalam hal ini kelembagaan yang terdiri dari stakeholder pariwisata (pemerintah, pelaku usaha, dan masyarakat) telah berani menunjukkan inovasi yang berupa pengambangan pariwisata halal. Konsep ini merupakan konsep baru dalam pariwisata di Indonesia. Adanya pro, kontra, serta banyak pertanyaan mengikuti proses Lombok menjadi destinasi 
halal. Kondisi ini tidak menghentikan upaya stakeholder di Lombok untuk tetap mengembangkan pariwisata halal. Perlahan tapi pasti, Lombok semakin memantapkan diri memberikan varian baru dalam pengembangan pariwisata. Adanya peran stakeholder berupa dukungan dan sinergisitas membuat nama Lombok semakin dikenal. Pro kontra serta berbagai macam pertanyaan yang sebelumnya ada perlahan terganti oleh apresiasi positif. Kondisi ini yang kemudian juga menimbulkan "aura" positif bagi pengembangan pariwisata di Lombok, khususnya dalam konsep pariwisata halal. Sehingga, hingga saat ini seluruh elemen pariwisata di Lombok saling bekerjasama untuk meningkatkan perkembangan pariwisata yang dalam jangka panjang berdampak pada kesejahteraan bersama. Sehingga konsep pengembangan pariwisata halal di Lombok dapat diimplementasikan dengan baik, selama antar stakeholder saling berkerjasama dan ersinergi dengan baik.

\section{Referensi}

[1]Dinas Kebudayaan dan Pariwisata Provinsi Nusa Tenggara Barat. (2016). Statistik Kebudayaan dan Pariwisata Provinsi Nusa Tenggara Barat 2016. Nusa Tenggara Barat. Tidak diterbitkan.

[2]Moleong, Lexy. J. (2006). Metodologi Penelitian Kualitatif. Bandung: PT Remaja Rosdakarya.

[3]Sekaran, Uma. (2006). Metode Penelitian Bisnis. Jakarta: Salemba Empat.

[4]Sugiyono. (2011). Metode Penelitian Pendidikan (Pendekatan Kuantitatif, Kualitatif, dan R\&D). Bandung: Alfabeta.

[5] Dinas Kebudayaan dan Pariwisata Provinsi Nusa Tenggara Barat. (2016). Statistik Kebudayaan dan Pariwisata Provinsi Nusa Tenggara Barat 2016. Nusa Tenggara Barat. Tidak diterbitkan 